\title{
THE EFFECT OF THIN CAPITALIZATION RULE TO CORPORATE CAPITAL STRUCTURE IN INDONESIA
}

\section{Muhammad Rheza Ramadhan, Riko Riandoko}

Kementerian Keuangan Republik Indonesia,Jakarta Politeknik Keuangan Negara-STAN,Tangerang Selatan

\section{A R T I C LE I N FO}

Keywords : Debt to Equity Ratio, Leverage, Agresivitas Pajak, Thin Capitalization

Kata Kunci: Debt to Equity Ratio, Leverage, Agresivitas Pajak, Thin Capitalization

Corresponding author :

Muhammad Rheza Ramadhan rhezakz@gmail.com
Abstract : This research finds the effect of thin capitalization rule implementation to corporate capital structure (debt and equity) in Indonesia. This study used leverage data in 2015 (before the implementation) and 2016 (after the implementation). The data was seperated with the leverage above 4:1 and below 4:1. The data was processed using paired sample t-test. Based on hand-collected sample of 76 publicity- listed indonesian firms for the 2015 and 2016 year, we found that the thin capitalization rule significantly affected corporate capital in both the sample with Debt to Equity Ratio above 4:1 and Debt to Equity Ratio below 4:1 and doesn't significantly affected corporate debt in both the sample with Debt to Equity Ratio above 4:1 and Debt to Equity Ratio below 4:1.

Abstrak :Penelitian ini berusaha menemukan pengaruh implementasi thin capitalization rule terhadap struktur modal (hutang dan ekuitas) perusahaan di Indonesia. Penelitian ini menggunakan data leverage pada tahun 2015 (sebelum implementasi) dan 2016 (setelah implementasi). Data dipisahkan menjadi data dengan leverage di atas 4:1 dan di bawah 4:1. Data diproses dengan menggunakan metode paired sample t-test. Berdasarkan pengumpulan data sampel pada 76 perusahaan masuk bursa di Indonesia pada tahun 2015 dan 2016, kami menemukan bahwa thin capitalization rule berpengaruh signifikan terhadap ekuitas perusahaan baik pada sampel dengan Debt to Equity Ratio lebih dari 4:1 maupun kurang dari 4:1 dan tidak berpengaruh signifikan terhadap hutang perusahaan baik pada sampel dengan Debt to Equity Ratio lebih dari 4:1 maupun kurang dari 4:1, 


\section{INTRODUCTION}

\section{Background}

In business, it has long been known that multinationals can use internal debt to shift profits from countries with low tax rates to countries with high tax rates (Mardan, 2013). Therefore, many countries try to make arrangements related to thin capitalization to limit the use of internal debt as a scheme of tax avoidance (Buttner et al., 2012).

The practice of the existence of thin capitalization in Indonesia has been known long ago by the Indonesian government, proved, in 1983 in Article 18 paragraph 1 Income Tax Law has been found general anti-avoidance rule for thin capitalization which then continued with the issuance of KMK-1002 / KMK.04 / 1984 which regulates that the firm's maximum debt to equity ratio is 3:1. Unfortunately, the implementation of this rule was delayed for 30 years so during that time, the Directorate General of Taxation did not have any technical rules that could regulate taxpayers who use thin capitalization as tax avoidance scheme. This causes tax avoidance practices (one of them is thin capitalization scheme) do by taxpayers (especially Foreign Investment) in Indonesia. As reported by Liputan 6 (2016), Director General of Taxes, Ken Dwijugiastiadi, states that as many as 2000 PMA has been losing (financial statement) for 10 years. Mekar Satria Utama, Director of Counseling, Services and Public Relations, Directorate General of Taxes, as quoted by CNN Indonesia (2016), added that the 2000 Foreign Investment Company losers mostly using the transfer pricing technique that one of the techniques can be done with thin capitalization.

In 2015, finally, the Regulation of the Minister of Finance Number PMK-169 / PMK.010 / 2015 stipulates that limit debt to equity ratio maximum $4: 1$. However, the release of this regulation can not be separated from the criticism, one criticism issued by Darussalam and Kristiaji (2015) which says that debt to equity ratio rule should consider the arm's length transaction by looking at business facts so tax payers can have debt to equity ratio exceeds 4: 1 as long as it conforms to existing business facts.

Prior research suggests that the existence of the thin capitalization rule causes a change in the capital structure of firms in the United States with a debt reduction of $43 \%$ (Blouin et al., 2014). Interestingly, research by Buettner et al. (2012) finds that although the internal debt (to affiliates) is reduced, this adds to the existence of external debt (non-affiliated) so the amount of leverage becomes fixed. Research in Indonesia related to the implementation of thin capitalization rule has also been done by Ramadhan et al. (2017a) which mentioned that there is no difference between the leverage of companies before and after the implementation of thin capitalization rule in Indonesia. But, in the study there are weaknesses where in Ramadhan et al. (2017a) the sample is not separated between companies having Debt to Equity Ratio of more than 4: 1 and less than 4: 1, whereas there should be different reactions between the two groups of companies. Further research was conducted by Ramadhan et al. (2017b), after the samples were separated into two groups (debt to equity ratio of more than 4:1 and less than $4: 1$ ), they found that the thin capitalization rule could reduce the debt to equity ratio of both companies with debt to equity Ratio more than 4: 1 and less than 4: 1. Only, in the study, Ramadhan et al. (2017b) did not explain whether the decline came from debt reduction or capital increase.

Therefore, we are interested to do research whether the decrease in debt to equity ratio in Ramadhan et al. (2017) is caused by a decrease in debt or an increase in capital. This study aims to find whether there is a significant difference between the company's capital structure (debt and capital) before and after the implementation of the thin capitalization rule in Indonesia.

\section{THEORY AND HYPOTHESIS DEVELOPMENT}

\section{Thin capitalization rule effect on Corporate Debt}

Research in the United States shows that the thin capitalization rule can reduce corporate debt in the United States by $43 \%$ (Blouin et al., 2014). The implementation of the thin capitalization rule in Indonesia also has a similar purpose to that applicable in the United States that is for companies to limit debt and change the structure of financing into share capital. Research in Indonesia related to the implementation of thin capitalization rule has also been done by Ramadhan et al. (2017b) which found that the thin capitalization rule could reduce the debt to equity ratio of both companies with debt to equity Ratio more than $4: 1$ and less than $4: 1$. Companies can reduce debt to 
equity ratio by reducing debt or increasing capital. Therefore, based on the theoretical basis above and previous research that exist, we makes two hypothesis:

H1: Thin capitalization rule can reduce corporate debt which has more than 4:1 leverage

$\mathrm{H} 2$ : Thin capitalization rule can reduce corporate debt which has less than 4:1 leverage

H3: Thin capitalization rule can increase corporate capital which has more than 4:1 leverage

H4: Thin capitalization rule can increase corporate capital which has less than 4:1 leverage

\section{Scope}

\section{RESEARCH DESIGN}

The scope of the research is all the company's financial statements in Indonesian stock exchanges in 2015 and 2016 with a limit on the companies which the annual report have been present in Indonesia Stock Exchange website.

\section{Data collection technique}

Sampling was done by purposive sampling technique to get the samples according to the purpose of this research. Sampling is done by eliminating the company as follows:

1. Companies whose 2016 annual report is not listed on the Indonesia Stock Exchange website;

2. Companies that have a negative Debt to Equity Ratio;

3. Companies included in outliers.

Data collection is done by taking the total value of debt and equity of sample companies in 2015 and 2016 using annual report data contained in the Indonesia Stock Exchange website. Data will be separated between companies that have Debt to Equity Ratio above 4:1 and under 4:1.

\section{Variable}

Variable to be studied in this research is corporate debt and corporate capital. Corporate debt is the entire debt of the corporate in the corporate's statement of financial position at the end of the fiscal year, while the capital is the entire company's equity in the corporate's statement of financial position at the end of the fiscal year. The variables will be transformed to natural logarithm form so that the differences between one with another not too far.

\section{Analysis Technique}

The data analysis is performed using different test of debt and capital in 2015 (before the implementation of PMK-169 / PMK.010 / 2015) with debt and capital in 2016 (after the implementation of PMK-169 / PMK.010 / 2015). The statistical tool that can be used to test the hypothesis is paired sample t-test (Ghozali, 2016). Testing is done using SPSS 23. Before performing t test, the authors also do descriptive statistical analysis to see the spread of data.

\section{Sampling}

\section{RESULT AND DISCUSSION}

Sampling is done by using purposive sampling method as follows and divided into two groups as follows:

$1^{\text {st }}$ Group: Companies with Debt to Equity Ratio Year 2015 more than 4: 1

For companies that have a Debt to Equity Ratio of more than 4: 1 sampling is done as follows:

Table 1. $1^{\text {st }}$ Group Sampling

\begin{tabular}{|c|c|}
\hline $\begin{array}{l}\text { Company which registered in } \\
\text { Indonesia Stock Exchange }\end{array}$ & 537 company \\
\hline $\begin{array}{l}\text { Companies whose annual report is } \\
\text { not listed on the Indonesia Stock } \\
\text { Exchange's Website }\end{array}$ & 461 company \\
\hline $\begin{array}{l}\text { Companies that have a Negative } \\
\text { Debt to Equity Ratio }\end{array}$ & 5 company \\
\hline Companies that have a Debt to & 64 company \\
\hline
\end{tabular}


Equity Ratio of less than 4: 1

Companies included in outlier

Samples 2 company

5 company

$2^{\text {nd }}$ Group: Companies with Debt to Equity Ratio Year 2015 less than 4: 1

For companies that have a Debt to Equity Ratio of less than 4:1 sampling is done as follows:

Table 2. $2^{\text {nd }}$ Group Sampling

Company which registered in 537 company

Indonesia Stock Exchange

Companies whose annual report is 461 company

not listed on the Indonesia Stock

Exchange's Website

Companies that have a Negative 5 company

Debt to Equity Ratio

Companies that have a Debt to 7 company

Equity Ratio of more than 4: 1

Samples

64 company

Descripstive Statistical Analysis

Descriptive statistical analysis was conducted to see the distribution of sample data. Descriptive statistical analysis was performed using the SPSS 23 application by looking at the mean (mean) and standard deviations of the sample firms. The results of descriptive statistical analysis can be seen in table 3, 4, 5, and 6 as follows:

Table 3. Descriptive Statistics $1^{\text {st }}$ Group Debt

$\begin{array}{llll}\text { Mean } & \text { N } & \text { Std. } & \text { Std. }\end{array}$

\section{Deviation Error}

\begin{tabular}{lllll}
\hline debt2015 & 12,3282 & 5 & 1,11628 &, 49922 \\
\hline debt2016 & 12,3545 & 5 & 1,00607 &, 44993
\end{tabular}

Table 4. Descriptive Statistics $2^{\text {nd }}$ Group Debt

\begin{tabular}{llllll}
\hline & & Mean & $\mathbf{N}$ & $\begin{array}{l}\text { Std. } \\
\text { Deviation }\end{array}$ & $\begin{array}{l}\text { Std. } \\
\text { Error } \\
\text { Mean }\end{array}$ \\
\hline Pair 1 & debt2015 & 11,7541 & 64 & 1,94717 &, 24340 \\
& debt2016 & 11,7254 & 64 & 1,98256 &, 24782
\end{tabular}

Table 5. Descriptive Statistics $1^{\text {st }}$ Group Equity

\begin{tabular}{llllll}
\hline & & Mean & N & $\begin{array}{l}\text { Std. } \\
\text { Deviation }\end{array}$ & $\begin{array}{l}\text { Std. } \\
\text { Error } \\
\text { Mean }\end{array}$ \\
\hline Pair 1 & equity2015 & 10,6201 & 5 & 1,02277 &, 45740 \\
\cline { 2 - 6 } & equity2016 & 11,0739 & 5 &, 82565 &, 36924 \\
\hline
\end{tabular}

Table 6. Descriptive Statistics $2^{\text {nd }}$ Group Equity 


\begin{tabular}{llllll}
\hline & & Mean & $\mathbf{N}$ & $\begin{array}{l}\text { Std. } \\
\text { Deviation }\end{array}$ & $\begin{array}{l}\text { Std. } \\
\text { Error } \\
\text { Mean }\end{array}$ \\
\hline Pair 1 & equity2015 & 11,8771 & 64 & 1,59422 &, 19928 \\
\cline { 2 - 6 } & equity2016 & 12,0119 & 64 & 1,45922 &, 18240 \\
\hline
\end{tabular}

In descriptive statistical analysis can be seen in $1^{\text {st }}$ group (Debt to Equity Ratio more than 4: 1), the mean of debt increase from 12,3282 in 2015 to 12,3545 in 2016 and the mean of equity increase from 10,6201 in 2015 to 11,0739 in 2016. Then, in Group 2 (Debt to Equity Ratio less than 4: 1), the mean of debt decrease from 11,7541 in 2015 to 11,7254 in 2016 and the mean of equity increase from 11,8771 in 2015 to 12,0119 in 2016.

\section{Hypothesis Testing}

Hypothesis testing is done by using paired sample $t$ test through SPSS 23 statistical application. In this research, the writer use Null Hypothesis Significance Testing (NHST) approach. To determine whether H0 is accepted or rejected, the author will use p-value assuming H0 is true (Field, 2013, 2.6.1.3). Therefore, parameters that are important to test the hypothesis in this study is on the significance of the variables studied. The level of trust used in this study is $95 \%$ which means $\mathrm{H} 0$ will be rejected if the probability value (sig in the IBM SPSS 23 application) is greater than 0.05 .

Based on the analysis of paired sample $t$ test results obtained as follows:

Table 7. Paired Sample t-test $1^{\text {st }}$ Group Debt

\begin{tabular}{llccc}
\hline & t & df & $\begin{array}{c}\text { Sig. (2- } \\
\text { tailed) }\end{array}$ \\
\hline Pair 1 & $\begin{array}{l}\text { debt2015 } \\
\text { debt2016 }\end{array}$ &,- 305 & 4 &, 775 \\
\hline
\end{tabular}

Table 8. Paired Sample t-test $2^{\text {nd }}$ Group Debt

\begin{tabular}{lllcr}
\hline & t & df & $\begin{array}{l}\text { Sig. (2- } \\
\text { tailed) }\end{array}$ \\
\hline Pair 1 & $\begin{array}{l}\text { debt2015 - } \\
\text { debt2016 }\end{array}$ &, 568 & 63 &, 572 \\
\hline
\end{tabular}

Table 9. Paired Sample t-test $1^{\text {st }}$ Group Equity

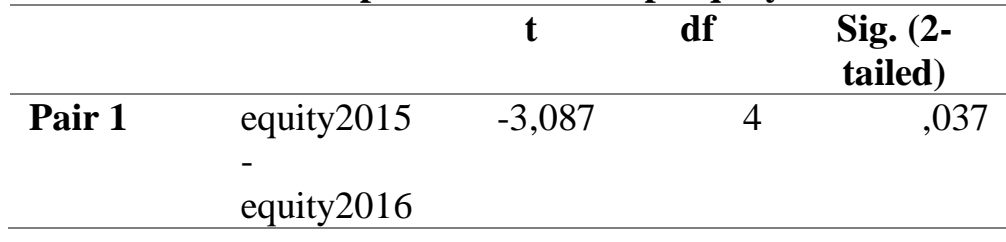

\begin{tabular}{|c|c|c|c|c|}
\hline & & $\mathbf{t}$ & df & Sig. (2-tailed) \\
\hline $\begin{array}{l}\text { Pair } \\
1\end{array}$ & $\begin{array}{l}\text { equity } 2015 \\
\text { equity } 2016\end{array}$ & $-2,329$ & 63 & ,023 \\
\hline
\end{tabular}

In table 7, it can be seen that the sig value of Paired Sample t-test for $1^{\text {st }}$ group debt is 0.775 which means H10 must be rejected, it means that in the sample of companies with Debt to Equity Ratio exceeding 4:1 in 2015, thin capitalization rule can't change the firm's debt significantly. Then, in table 8 it can be seen that the sig value of Paired Sample t-test for $2^{\text {nd }}$ group debt is 0.572 which means $\mathrm{H} 20$ must also be rejected, it means that in the sample of companies with Debt to Equity Ratio less than 4: 1 in 2015, the presence of a thin capitalization rule can't 159 
change the firm's debt. Then, in table 9 , it can be seen that the sig value of Paired Sample t-test for $1^{\text {st }}$ group equity is 0,037 which mean H30 must be accepted, it means that in the sample of the companies with Debt to Equity Ratio exceeding 4:1 in 2015 , thin capitalization rule can change the firm's equity significantly. Then, in table 10 , it can be seen that the sig value of Paired Sample t-test for $2^{\text {nd }}$ group equity is 0,023 which mean H40 must be accepted, it means that in the sample of the companies with Debt to Equity Ratio less than 4:1 in 2015, thin capitalization rule can change the firm's equity significantly.

\section{Discussion}

Based on descriptive statistical analysis and hypothesis testing in the previous section, it can be seen that for the sample in the first and second group, the debt does not change significantly due to the thin capitalization rule, while the equity value changes significantly due to the thin capitalization rule. Based on the results of descriptive statistics can also be seen that the value of equity increased in 2016, this indicates that the decrease in debt to equity ratio in 2016 in the first and second group of samples found by Ramadan et al. (2017b) is not caused by a decrease in debt, but is caused by an increase in equity. This is contrary to the research of Blouin et al. (2014) who finds that in the United States debt may decrease due to the thin capitalization rule.

\section{CONCLUSION AND SUGGESTION}

In the business world, both in Indonesia and internationally, companies (especially multinational) tend to capitalize on the difference in tax treatment between dividends and interest to avoid taxes using thin capitalization schemes. Therefore, many countries issue regulations on the thin capitalization rule. Indonesia, in 2015, has also issued a thin capitalization rule that is at PMK-169/PMK.010/2015 which limits the value of Debt to Equity Ratio to $4: 1$.

Based on paired sample $t$ test test that is divided into two groups: first group (Debt to Equity Ratio more than 4:1) and second group (Debt to Equity Ratio less than 4:1), it can be seen that for the sample in the first and second group, the debt does not change significantly due to the thin capitalization rule, while the equity value changes significantly due to the thin capitalization rule. Based on the results of descriptive statistics can also be seen that the value of equity increased in 2016, this indicates that the decrease in debt to equity ratio in 2016 in the first and second group of samples found by Ramadan et al. (2017b) is not caused by a decrease in debt, but is caused by an increase in equity.

Based on the results, we can advise some parties such as to the next researchers or to the Directorate General of Tax as follows:

1. To the next researchers:

2. Next researchers can use more complex methods to analyze the effect of thin capitalization rule on corporate capital structure, such as the difference in difference method.

3. To Directorate General of Taxation:

4. The Directorate General of Taxation should pay more attention to the reasonableness of taxpayer debt in Indonesia because based on research results, it is found that the thin capitalization rule can not reduce the company's debt, but only increase the company's capital. While, one of the objectives of the thin capitalization rule is to reduce the cost of debt arising such as interest expense and foreign exchange loss. Therefore, it can be said that the main goal of the thin capitalization rule can not be achieved.

\section{REFERENCES}

[1] CNN Indonesia. (2016, Oktober 30). Retrieved from CNN Indonesia: http://www.cnnindonesia.com/ekonomi/20160328115246-78-119992/djp-bongkar-motif-2000-perusahaanyang-kemplang-pajak

[2] Field, A. (2013). Discovering Statistc Using IBM SPSS Statistics (4th Edition). London: SAGE Publications.

[3] Ghozali, I. (2016). Aplikasi Analisis Multivariate dengan Program IBM SPSS 23. Semarang: Badan Penerbit Universitas Diponegoro.

[4] Jennifer Blouin, e. a. (2014). Thin Capitalization Rules and Multinational Firm Capital Structure. CEFR Discussion Paper 9830 , 1-2. 
[5] Liputan 6. (2016, September 19). Retrieved from Liputan 6: http://bisnis.liputan6.com/read/2469089/2000perusahaan-asing-gelapkan-pajak-selama-10-tahun

[6] Mardan, M. (2013). The Effects of Thin Capitalization Rules when Firms are Financially Constrained. Norwegian Center of Taxation .

[7] Ramadhan, Muhammad Rheza, Frandiyanto, Satria Agus, and Riandoko, Riko (2017a). Pengaruh Thin Capitalization Rule terhadap Leverage Perusahaan Masuk Bursa di Indonesia. Not yet Published.

[8] Ramadhan, Muhammad Rheza, Frandiyanto, Satria Agus, and Riandoko, Riko (2017b). Pengaruh Thin Capitalization Rule pada Leverage Perusahaan di Indonesia: Studi Perbandingan antara Perusahaan yang Memiliki Debt to Equity Ratio lebih dari 4:1 dan kurang dari 4:1. Not yet Published.

[9] Richardson, G., Taylor, G., \& Lanis, R. (2013). Determinants of Transfer Pricing Aggressiveness. Journal of Contemporary Accounting \& Economics 9 , 136-150.

[10] T. Buttner, M. O. (2012). The Impact of Thin Capitalization Rules on The Capital Structure of Multinational Firms. Journal of Public Economics 96 , 930-938 